\title{
PENEGAKAN HUKUM TERHADAP HAK ASUH ANAK AKIBAT PERCERAIAN DALAM PRAKTIK PERADILAN DI BALI ${ }^{1}$
}

\author{
Oleh : \\ Ni Nyoman Sukerti \\ I Gusti Ayu Agung Ariani \\ I Gst. A. A. Ari Krisnawati
}

ABSTRACT

Our research aims to find and analyze the laws applied by judge to custody of children due to divorce related to the enactment of legal pluralism. Related to this, the issues raised in this research are: 1). What law applied by judges to child custody of divorce related to the enactment of legal pluralism? 2). What factors are the basis for consideration of the judge in determined custody of children divorce?.

The results showed that the judge in determined custody of children of divorce apply national law. That is child to custody by mother may or paternal. Children who are under the care of the mother did not lose the right to inherit the father's side. The factors on which the consideration of the judge in determining child custody is a national marriage law, the cause of the divorce, and ensuring the interests the future of children, parenting by mothers did not abort child right inherit the father's side.

The conclusion that the judge in determined the custody of children due to divorce apply national law. The factors on which the consideration of the judge in determining child custody is a national law, the cause of the divorce, and ensuring the interests of future child, parenting did not abort of child in her father's right to inherit.

Keywords: child custody rights, divorce, judicial practice.

\section{PENDAHULUAN}

\section{I.I. Latar Belakang Masalah}

Sebelum tahun 1974, di Indonesia aturan-aturan tentang perkawinan tersebar dalam berbagai peraturan seperti Burgerlijk

Tulisan ini hasil penelitian dengan dana Dipa BLU Program Studi Magister (S2) Ilmu Hukum PPS Universitas Udayana tahun 2014 dan sudah diseminarkan.

2 Para penulis Dosen Program Studi Magister (S2) Ilmu Hukum Program Pascasarjana dan Fakultas Hukum Universitas Udayana.
Wetboek, Hukum Perkawinan Kristen, dan aturan-aturan tidak tertulis seperti hukum adat yang berlaku diberbagai wilayah, serta hukum agama. Setelah berlakunya UndangUndang Nomor 1 Tahun 1974 tentang Perkawinan, aturan tentang perkawinan diatur secara nasional yang berarti hanya berlaku satu kesatauan hukum dalam bidang perkawinan. Diaturnya hukum perkawinan secara nasional tidak secara otomatis semua aturan seperti tersebut di atas tidak berlaku 
lagi, namun masih ada peluang bagi aturan tidak tertulis seperti hukum adat untuk tetap berlaku. Hukum adat sebagai hukum tidak tertulis masih tertap berlaku tercermin dalam ketentuan Pasal 66 Undang-Undang Perkawinan.

Penegakan hukum dalam praktik peradilan terhadap hak asuh anak sebagai akibat dari perceraian dapat berlaku lebih dari satu sistem hukum. Hal ini dapat diketahui dari masih berlakunya pluralisme hukum sampai saat ini yaitu hukum tertulis dan hukum tidak tertulis. Berlakunya pluralisme sistem hukum dapat berdampak dalam penegakan oleh hakim terhadap suatu masalah hukum terkait hak asuh anak akibat perceraian. Udang-Undang No. 1 Tahun 1974, tetap memberi peluang berlakunya hukum tidak tertulis. Yang dimaksudkan hukum tidak tertulis disini adalah tidak tertulis dalam peraturan perundang-undangan Republik Indonesia atau peraturan legislatif seperti awig-awig di Bali, Kuntara Raja Niti dan Raja Asa di Lampung dan lain-lainnya ${ }^{3}$.

Hukum adat merupakan hukum hasil konstruksi dari pada masyarakat hukum adat, dimana masyarakat hukum adat dan hak-hak tradisionalnya diakui dan dihormati oleh negara berdasarkan Pasal 18 B ayat 2 UUD 1945 (hasil amandemen kedua). Ini berarti hukum adat tetap berlaku di wilayah lingkaranberlakunyamasing-masing, dimana Van Vollenhoven sebagaimana dikutip
Soepomo, membagi lingkaran berlakunya hukum adat menjadi 19 lingkaran ${ }^{4}$.

Dengan masih berlakunya pluralisme hukum di Indonesia dan khususnya di Bali terkait dengan hak asuh anak akibat perceraian akan berdampak pada penegakan hukum dalam praktik peradilan. Hal mana mengingat masyarakat Bali Hindu menganut sistem kekerabatan patrilineal yang sangat kuat dengan bentuk perkawinan jujur. Dalam perkawinan jujur dimana istri mengikuti suami dan anak-anak yang lahir mengikuti garis ayah. Sehubungan dengan hal tersebut maka apabila terjadi perceraian maka akan menimbulkan akibat hukum salah satunya adalah hak asuh anak. Terkait dengan itulah maka penelitian ini menjadi penting untuk dilakukan.

\subsection{Rumusan Masalah}

Berdasarkan apa yang sudah diuraikan di atas maka masalah penting yang menjadi fokus dalam penelitian ini sebagai berikut :

1. Hukum apakah diterapkan oleh hakim terkait hak asuh anak akibat perceraian dalam hal berlakunya pluralisme hukum?

2. Faktor-faktor apakah yang menjadi dasar pertimbangan hakim dalam menetapkan hak asuh anak akibat perceraian?
I Gede A.B. Wiranata, Hukum Adat Indonesia (Perkembangannya dari Masa ke Masa), PT Citra Aditya Bakti, Bandung, 2005, hlm. 67.
R. Soepomo, Bab-Bab tentang Hukum Adat, Pradnya Paramita, Jakarta, 1986, hlm. 56. 


\section{METODE PENELITIAN}

\section{Pendekatan}

Pada penelitian ini, pendekatan dipergunakan adalah pendekatan nondoktrinal (socio-legal approach). Pendekatan tersebut menurut Sorjono Soekantodigunakanuntukmemahamihukum dalam konteks masyarakatnya ${ }^{5}$. Sementara Brian Z. Tamanaha mengungkapkan bahwa hukum dan masyarakat mempunyai bingkai (The Law Society Framework) dimana hal tersebut mempunyai hubungan yang sangat erat. Hubungan tersebut mencakup dua komponen dasar. Adapun komponen dimaksud dimana hukum merupakan cermin masyarakat dan fungsinya adalah untuk mempertahankan "social order". Di samping itu hukum, terdiri dari tiga elemen, yaitu: custom/consent; morality/reason; dan positive law. ${ }^{6}$ Custom/consent and morality/ reason dapat dipahami dari pemikiran Donald Black sebagai culture.

\section{Jenis Penelitian}

Penelitian ini adalah penelitian hukum empiris, dinama dasar penekanan pada data primer atau data lapangan. Walaupun demikian penelitian ini diawali dengan data sekunder sebagai data awal. Penelitian hukum empiris tetap bertumpu pada premis normatif yang menngkaji esensi hukum dalam bentuk norma-norma baik hukum tertulis (perundang-undangan) maupun hukum tidak tertulis (hukum ada), kemudian

Soerjono Soekanto, Pendekasan Sosiologis Terhadap Hukum, PT Bina Aksara, Jakarta, 1988, hlm. 9.

6 Brian Z. Tahamaha, Jurisprudence of Law and Society. Oxford University Press, New York, 2006, hlm. 1-2. A General dikaitkan dengan fakta dilapangan praktik peradilan. Hal tersebut selaras dengan pandangan Morris L. Chohen, Kent C. Olson berikut ini, "legal research is an essential component of legal practice. It is the process of finding the law that governs an activity and materials that explain or analyze that law ${ }^{67}$.

\section{Tempat Penelitian}

Penelitian ini dilakukan di Pengadilan Negeri di Bali sebagai populasi dengan pengambil beberapa Pengadilan Negeri sebagai sampel.

\section{Informan}

Pada penelitian ini para informannya adalah para hakim dalam fungsinya sebagai penegak hukum. Para hakim tersebut baik yang pernah maupun yang tidak pernah menangani kasus terkait kasus hak asuh anak sebagai akibat perceraian.

\section{Teknik penggalian data.}

Untuk mendapatkan data yang valid, data digali dengan teknik wawancara (interview) dengan alat bantu instrumen berupa pedoman pertanyaan agar wawancara terarah dan fokus tentang permasalahan.

\section{Teknik Pengolahan dan Analisis Data.}

Pengolahan dan analisis data digunakan metode yang bersifat kualitatif dan tidak menggunakan analisis statistik. Metode ini akan dapat menunjukan tugas hakim sebagai penegak hukum terkait hak asuhanak akibat perceraian.

Morris L. Chohen \& Ken C. Olson, Legal Research, West Publishing Company, St. Paul, Minn, 1992, hlm. 1 . 


\section{HASIL DAN PEMBAHASAN}

\section{Hukum Yang Diterapkan Hakim Terkait Hak Asuh Anak Akibat Perceraian Dalam Hal Berlakunya Pluralisme Hukum.}

Undang-Undang perkawinan adalah unifikasi hukum perkawinan yang bersifat unik kata Hazairin. Bersifat unik karena sebagai suatu unifikasi hukum di bidang perkawinan, masih memberi peluang berlakunya hukum perkawinan adat.

Perkawinan yang dilakukan dalam suatu masyarakat tidak dapat dipisahkan dari sistem kekerabatan yang dianut oleh masyarakat yang bersangkutan. Di Indonesia pada prinsifnya dikenal tiga sistem kekeluargaan yaitu sistem patrilineal (garis ayah), sistem matrilineal (garis ibu) dan sintem parental (garis ayah-ibu). Terkait sistem kekeluargaan tersebut, Bushar Muhammad mengemukakan bahwa dalam melihat garis keturunan ada tiga cara sebagai berikut:

1. Pertalian keturunan patrilineal atau sistem kekerabatan patrilineal yang dianut di daerah Batak, Lampung, Bali, dan lain-lainnya.

2. Pertalian keturunan matrilineal atau sistem kekeluargaan matrilineal. Sistem ini dianut di Minangkabau, Kerinci dan lain sebagainya.

3. Pertalian keturunan yang dilihat baik menurut garis laki-laki (ayah) maupun menurut garis perempuan (ibu), atau menurut garis dua sisi (ayah-ibu). Sistem tersebut disebut keturunan parental atau kekeluargaan parental yang dianut di daerah Aceh, Bugis, Riau, Kalimantan dan Jawa ${ }^{8}$.

Masing-masing sistem kekerabatan yang dianut oleh suatu masyarakat akan berpengaruh terhadap bentuk perkawinan yang dilakukan, dan bentuk perkawinan yang dilakukan berpengaruh terhadap akibat perceraian terkait dalam persoalan pengasuhan anak.

Pada masyarakat yang menganut sistem kekerabatan atau kekeluargaan patrilineal, ciri khas bentuk perkawinan jujur. Jujur dapat berbentuk uang atau barang, akan tetapi yang lebih umum jujur itu dalam bentuk uang sehingga disebut uang jujur atau "pembelian". Fungsi jujur adalah secara yuridis untuk mengubah status keanggotaan clan dari pengantin perempuan, secara ekonomis membawa pergeseran dalam kekayaan, dan secara sosial tindakan penyerahan jujur itu mempunyai arti fihak perempuan mempunyai kedudukan yang dihormati9.

Sementara dalam masyarakat yang menganut sistem kekerabatan matrilineal, tidak ada pembayaran jujur, apabila terjadi perceraian maka anak-anak berada di bawah pengasuhan ibu dan keluarganya. Pada masyarakat yang menganut sistem kekerabatan parental, apabila terjadi perceraian hak asuh anak-anak berada pada ayah ataupun ibu tergantung dari kesepakatan di pihak mana lebih terjamin kehidupannya.

Bushar Muhammad, Loc. Cit.

Djaren Saragih, Pengantar Hukum Adat Indonesia, Tarsito, Bandung, 1980, hlm. 135. 
Terkait ketiga sistem kekerabatan tersebut, masyarakat Bali Hindu menganut sistem kekerabatan patrilineal yang lebih dikenal dengan sistem purusa. Pada sistem ini apabila terjadi perceraian maka hak pengasuhan anak-anak berada di tangan ayah dan keluarganya kecuali dalam perkawinan nyentana atau nyeburin.

Mengenai hak asuh anak karena perceraian berada pada ayah dan keluarga purusa juga diungkap oleh Sudantra. Menurutnya jika terjadi perceraian otomatis hak asuh anak jatuh kepada ayahnya dan terikat oleh keluarga purusa ${ }^{10}$

Pada masyarakat Bali Hindu putusnya perkawinan karena perceraian dimana hak asuh anak-anak berada pada pihak ayah dan keluarganya, oleh karenanya dapat menimbulkan persoalan mengingat sudah berlakunya hukum nasional di bidang perkawinan. Pokok kajiannya adalah penegakkan hukum oleh hakim terhadap hak asuh anak akibat perceraian dalam praktik peradilan mengingat masih berlakunya pluralisme hukum.

Sebuah perkawinan tidak semuanya berjalan sesuai dengan yang direncanakan sebelumnya akan tetapi ada perkawinan yang berakhir karena perceraian. Perceraian dapat menimbulkan akibat-akibat yaitu akibat terhadap bekas suami dan bekas istri, akibat terhadap anak-anak dan akibat terhadap harta perkawinan atau harta bersama. Bekas suami maupun bekas istri dapat kawin lagi,

10 I Ketut Sudantra, I Gusti Ngurah Sudiana, Komang Gede Narendra, Perkawinan Menurut Hukum Adat Bali, Udayana Universiry Press, 2011, hlm. 112 sementara terhadap anak-anak dalam hal hak asuh tergantung sistem kekerabatan yang dianut oleh bekas pasangan suami istri tersebut.

Dengan berlakunya Undang-Undang Perkawinan dimana masalah perkawinan dan perceraian sudah diatur secara nasional, tetapi hukum adat masih mempunyai peluang untuk berlaku, lantas bagimana penegakkan hukum terhadap hak asuh anak akibat perceraian dalam praktik peradilan.

Berbicara mengenai penegakkan hukum tiada lain adalah berbicara mengenai pelaksanaan hukum itu sendiri oleh para penegak hukum. Terkait hal itu, Satjipto Rahardjo menyatakan bahwa penegakan hukum sebenarnya adalah suatu proses untuk mewujudkan keinginan-keinginan hukum menjadi kenyataan, yang puncaknya pada pelaksanaan hukum oleh pejabat penegak hukum yang bersangutan ${ }^{11}$. Dalam penegakan hukum sebenarnya berkaitan dengan hukum sebagai suatu sistem yang terdiri dari stuktur, substansi dan budaya hukum. Sementara Van Dijk dalam Abdurrahman menyatakan bahwa ..., hukum harus dipahami dengan latar belakang masyarakat yang seluas-luasnya. ...Semua peran ganda... memperlihatkan sifat ... khaostis, ... fungsi dari sistem mereduksi kompleksitas tersebut .... dengan cara tersebut kehidupan menjadi tertata dan kepastian dalam masyarakat dapat terciptakan ... ${ }^{12}$

Satjipto Rahardjo, Op.Cit., hlm. 24.

12 Abdurrahman, Ilmu Hukum, Teori Hukum dan Ilmu Perundang-Undangan, PT Citra Aditya Bakti, Bandung, 1995, hlm. 129. 
Sementara Munir Fuady, menguraikan penegakan hukum (law enforcement) tiada lain dari upaya, proses yang dilakukan dan dpertanggung jawabkan kepada pemerintah dan aparan-aparatnya atau kepada pihak yang didelegasikan. Di samping itu, dalam hal-hal tertentu juga dilakukan oleh pihak swasta, profesional, atau masyarakat untuk mewujudkan ide, konsep, dan kaidah hukum tertulis atau tidak tertulis, yang bersifat normatif, dan umumnya abstrak untuk diwujudkan ke dalam fakta-fakta, kasus, dan kenyataan masyarakat ${ }^{13}$

Undang-Undang Perkawinan mengatur putusnya perkawinan dalam Bab VIII Pasal 38. Pasal 38 mengatur putusnya perkawinan putus karena kematian, perceraian, dan karena keputusan Pengadilan.

Masalah perceraian diatur pada Pasal 39. Pada pasal tersebut ditentukan bahwa perceraian hanya dapat dilakukan didepan sidang Pengadilan.

Terkait dengan ketentuan Pasal 39 tersebut, dimana perceraian hanya dapat dilakukan di depan sidang Pengadilan, ini berarti perceraian secara adat tidak dapat diberlakukan lagi. Oleh karena demikian maka akibat-akibat hukum putusnya perkawinan karena perceraian juga sudah diatur dalam undang-undang tersebut.

Akibat putusnya perkawinan karena perceraian diatur pada Pasal 41. Inti pasal tersebut, dimana baik ibu atau bapak tidak dapat lepas dari kewajiban memelihara dan

Munir Fuady, Sosiologi Hukum Kontemporer, Interaksi Hukum, Kekuasaan, dan Masyarakat, PT. Citra Aditya Bakti, Bandung, 2007, hlm. 107. mendidik anak-anaknya dan bertanggung jawab atas biaya pemeliharaan anak-anak. Terkait dengan hal tersebut lantas bagaimana dalam praktiknya apakah para hakim menjatuhkan putusan berdasarkan ketentuan U U No. 1 Th. 1974 atau hukum adat sebagai the living law.

Pada penelitian ini difokuskan pada hak asuh anak karena perceraian melalui proses di Pengadilan. Terkait dengan hal itu dikemukan pendapat dari para hakim Pengadilan Negeri di Bali berikut ini.

Hasoloan Sianturi ${ }^{14}$ hakim Pengadilan Negeri Denpasar mengemukakan bahwa dalam memutus perkara perceraian ikut juga diputuskan mengenai hak pengasuhan anakanaknya. Yang menjadi dasar pertimbangan menjatuhan hukum hak pengasuhan anak adalah hukum perkawinan nasional, penyebab perceraian, demi kepentingan si anak. Hak pengasuhan anak ada yang jatuh kepada ayah dan ada juga jatuh kepada ibu. Jadi tetap berpedoman pada hukum nasional tetapi tetap menghargai nilai-nilai hukum adat. Artinya setelah anak-anak yang bersangkutan dewasa maka kembali pada aturan hukum adat Bali yang masih begitu kuat dipertahankan, dimana anak-anak menurut hukum adat Bali adalah masuk garis ayah (patrilineal).

Pendapat hakim tersebut di atas dapat diketahui dari Putusan Pengadilan Negeri Denpasar Nomor: 361/Pdt.G/2014/PN Dps. Dalam putusan tersebut dinyatakan bahwa: hak asuh anak ditetapkan pada ibunya,

14 Hasoloan Sianturi, Hakim Pengadilan Negeri Denpasar, Wawancara tanggal 18 September 2014 
tetapi ayah dapat setiap saat menjenguknya. Sementara dalam Putusan Pengadilan Negeri Denpasar Nomor: 444/Pdt.G/2014/ PN Dps dinyatakan bahwa hak asuh anak ditetapkan pada bapaknya dan si tetap bisa menjenguknya.

Mencermati kedua Putusan Pengadilan Negeri Denpasar tersebut, putusnya perkawinan karena perceraian maka hak asuh anak ada jatuh kepada ibu dan ada juga jatuh kepada ayah. Ini berarti hakim sudah mempertimbangan secara matang demi kepentingan anak, tidak berdasarkan sistem patrilineal yang berlaku di Bali.

Pendapat yang tidak jauh berbeda juga dikemukakan Ni Kadek Kusuma Wardani ${ }^{15}$, hakim di Pengadilan Negeri Tabanan. Dikatakanbahwakasusperceraianmenempati urutan yang paling banyak hampir mencapai $95 \%$ dari perkara yang masuk, dan gugatan lebih banyak diajukan oleh istri, yakni hampir $87 \%$. Dalam menjatuhkan putusan, dipakai hukum nasional. Hak pengasuhan anak diberikan tergantung dari penyebab terjadinya perceraian, kepentingan dan masa depan anak. Sekalipun masyarakat Bali menganut sistem kekeluargaan patrilineal, tidak serta merta hak pengasuhan anak jatuh kepada ayah, dalam hal status keluarga tetap masuk garis purusa, karena ini terkait dengan hak waris nantinya.

Pendapat hakim itu dapat diketahui dari putusan-putsan berikut ini. Putusan Pengadilan Nomor: 42/Pdt.G/2014/PN. Tbn menetapkan bahwa hak asuh anak jatuh

15 Ni Kadek Kusuma Wardani, Hakim Pengadilan Tabanan, Wawancara tanggal 11 September 2014. pada ibu. Sementara pada Putusan Nomor: 14/Pdt.G/2014/PN.Tbn. menyatakan bahwa hak asuh anak jatuh pada bapak sebagai purusa.

Sementara I Ketut Darpawan, ${ }^{16}$ hakim Pengadilan Negeri Semarapura, Darpawan menjelaskan bahwa mengenai hak asuh anak dapat diberikan kepada ibunya tetapi ada juga kepada bapaknya sekalipun di Bali sistem purusa dijunjung tinggi dari dulu hingga kini. Hal itu demi kepentingan dan masa depan anak, di samping itu juga dipertimbangkan alasan-alasan perceraian dari suami istri yang bersangkutan.

Made Adi Candra Purnawan ${ }^{17}$, hakim Pengadilan Negeri Gianyar, mengungkapkan bahwa anak-anak yang masih di bawah umur sebagian besar berada pada pengasuhan ibu sampai anak tersebut dewasa, dan ini sesuai ketentuan Hukum Perkawinan Pasal 41 ayat 1 dan Pasal 47 ayat 1 dan 2, walaupun di Bali berlaku sistem kekerabatan patrilineal. Dalam menentukan hak asuh anak, yang paling penting terjaminnya masa depan anak.

Mengenai hak asuh anak bisa jatuh ke tangan ibunya atau bapaknya sebagai mana dikemukakan oleh hakim tersebut di atas dapat diketahui dari putusan Putusan Pengadilan Negeri Semarapura Nomor: 28/ PDT/2011//PN.Sp. yang menetapkan anakanaknya berada dalam pengasuhan ibunya sampai anak dapat menentukan sendiri

I Ketut Darpawan, Hakim Pengadilan Negeri Semarapura, wawancara, tanggal 17 September 2014.

17 Made Adi Candra Purnawan, Hakim Pengadilan Negeri Gianyar, Wawancara tanggal 11 September 2014. 
sikapnya, dan putusan Pengadilan Negeri Semarapura Nomor : 02/PDT.G/2012/ PN.SP, dinyatakan bahwa anak-anak berada pada pengasuhan bapaknya.

Dari beberapa pendapat hakim Pengadilan Negeri tersebut di atas pada dasarnya tidaklah jauh berbeda dalam menetapkan hak asuh anak. Hak pengasuhan anak dapat diberikan kepada ayah maupun kepada ibu dengan dasar pertimbangan demi kepentingan si anak. Penerapan hukumnya adalah Hukum Perkawinan Pasal 41 (1) dan Pasal 47 (1), Undang-Undang Perlindungan Anak Pasal 26 ayat 1, sekalipun masyarakat Bali Hindu menganut sistem kekeluargaan patrilineal yang di Bali dikenal dengan sistem purusa. Hak pengasuhan anak yang berada di tangan sang ibu tidak menghilangkan hak waris anak-anak pada ayahnya, karena masalah pewarisan tetap berlaku hukum adat waris Bali.

Terkait hal anak yang diasuh ibunya akibat adanya perceraian diungkap oleh Sudantra $^{18}$, bahwa berdasarkan tradisi masa lalu jika anak terlalu lama ikut ibunya ada potensi hak warisnya gugur. Lamanya waktu si anak diasuh ibunya berdasarkan putusan pengadilan adat (raad van kertha) yaitu 6 (enam) bulan.

Penegakan hukum dalam praktik peradilan di atas relevan dibedah dengan Teori Sistem Hukum yang dikemukakan oleh L.M. Friedman. Berdasarkan teori sistem hukum, bahwa hukum merupakan suatu sistem terdiri dari tiga komponen

18 I Ketut Sudantra, I Gusti Ngurah Sudiana, Komang Gede Narendra, Loc.Cit. yaitu struktur hukum, substansi hukum dan budaya hukum ${ }^{19}$. Berdasarkan ketiga komponen hukum tersebut yaitu komponen struktur hukum, substansi hukum dan budaya hukum sudah teraplikasikan dalam memutus suatu perkara terkait hak asuh anak akibat perceraian dalam praktik peradilan.

Hal tersebut juga relevan dikaji dari Semi Autonomous Social Field Theory yang dikemukakan oleh Sally Falk Moore ${ }^{20}$. Inti dari terori tersebut dimana hukum negara berlaku kuat maka hukum lokal (adat) berlaku lemah. Berdasarkan terori tersebut dimana hakim dalam menerapkan hukum terhadap hak asuh anak akibat perceraian adalah menerapkan hukum negara yakni Hukum Perkawinan. Ini berarti posisi hukum negara berlaku kuat sementara posisi hukum adat berlaku lemah.

\section{Faktor-Faktor Yang Menjadi} Dasar Pertimbangan Hakim Dalam Menetapkan Hak Asuh Anak Akibat Perceraian

Penegakan hukum adalah merupakan upaya untuk mewujudkan cita hukum dalam kenyataan di masyarakat. Penegakan hukum juga mengenai bagaimana bekerjanya hukum dalam masyarakat, karena masyarakat merupakan muaranya hukum. Siapa yang dimaksud penegak hukum? Mengenai penegak hukum adalah orang-orang atau

L.M. Friedman, Law and Society, anIntruduction, Printice Hall, New Jersey, 1977, hl. 7.

20 Sally Falk Moore, "Hukum dan Perubahan Sosial : Bidang Sosial Semi Otonomi Sebagai Suatu Studi Yang Tepat", dalam Antropologi Hukum Sebuah Bunga Rampai, Penyunting T.O. Ihromi, Yayasan Obor, Jakarta, 2001, hlm. 154. 
lembaga yang diberi wewenang untuk melaksanakan hukum tersebut seperti polisi, jaksa, hakim, birokrat dan lain sebaginya. Dalam penelitian ini penegak hukum dimaksudkan adalah hakim dalam fungsinya menjalankan hukum terhadap suatu perkara.

Dalam penegakan hukum oleh para penegak hukum, ada beberapa faktor yang dapat berpengaruh mengenai berasil tidaknya penegakan hukum tersebut. Sehubungan dengan penegakan hukum faktor yang paling berpengaruh adalah penegak hukum itu sendiri dan juga lingkungan sosialnya.

Terkait dengan penegakan hukum, Soerjono Soekanto mengemukakan ada beberapa yang mempengaruhinya yaitu:

1. Hukumnya sendiri, yakni peraturan yang berlaku umum dan peraturan yang berlaku pada wilayah tertenttu.

2. Penegak hukumnya, yakni mereka yang membentuk dan menerapkan hukum seperti polisi, hakim, jaksa, pengacara).

3. Sarana atau fasilitas yang mendukung penegakan hukum tersebut seperti tenaga manusia yang berpendidikan terampil, organisasi yang baik, peralatan yang memadai, keuangan yang cukup.

4. Masyarakat, yakni lingkungan sosial dimana hukum itu diberlakukan diartikan sebagai ilmu pengetahun, sebagai kaedah atau norma, sebagai tata hukum (hukum positif tertulis) dan lain-lainnya

5. Kebudayaan, yakni hasil karya, cipta dan rasa yang didasarkan pada karsa manusia di dalam pergaulan hidup dalam arti kebudayaan materiil maupun non-materiil ${ }^{21}$.

Sementara Satjipto Rahardjo, mengemukakan bahwa penegak hukum dalam melakukan fungsinya dipengaruhi oleh faktor manusianya sendiri secara pribadi, dan faktor lingkungan ${ }^{22}$. Selanjutnya Van Doorn sebagaimana dikutip Satjipto Rahardjo mengatakan bahwa dalam kedudukannya sebagai pemegang fungsi di dalam suatu organisasi, seorang penegak hukum cendrung menjalanlan fungsinya menurut tafsirannya sendiri yang dilatarbelakangi berbagai faktor ${ }^{23}$. Hal yang tidak jauh berbeda juga dijelaskan oleh Jerome Frank bahwa seorang hakim dalam mengambil keputusan dipengaruhi oleh prasangka politik, ekonomi dan moral bahkan simpati dan antipati pribadi ikut berperan ${ }^{24}$.

Penegakan hukum dalam praktik peradilan terkait pengasuhan anak akibat perceraian, dari keterangan beberapa hakim pada prinsipnya tidaklah jauh berbeda. Pengasuhan anak, ada ditetapkan pada sang ibu ada juga pada sang ayah. Ditetapkannya hak asuh anak di tangan ibu maupun ayah oleh hakim dipengaruhi oleh beberapa faktor sebagai berikut yaitu:

1. Hukum Perkawinan (Pasal 41 ayat 1, Pasal 47 ayat 1) U U Perlindungan

SoerjonoSoekanto,Faktor-FaktorYangMempengaruhi Penegakan Hukum, Raja Grafindo Persada, Jakarta, 1983, hlm. 5.

22 Satjipto Rahardjo, Op.Cit. hlm. 27.

Satjipto Rahardjo, Loc.Cit.

24 Theo Huijbers, Filsafat Hukum dalam Lintasan Sejarah, Kanisius, Yogyakarta, 1982, hlm. 78. 
Anak (Pasal 26 ayat 1).

2. Hal-hal yang menjadi menyebabkan terjadinya perceraian.

3. Kepentingan si anak, dimana anakanak dipandang merasa lebih nyaman dan aman berada serta terjaminnya masa depan si anak.

4. Pengasuhan anak-anak di tangan sang ibu tidak menyebabkan gugurnya hak mewaris si anak pada si ayah

5. .Sistem kekeluargaan patrilineal yang berlaku di Bali tidak mempengaruhi hakim dalam menetapkan hak asuh anak akibat perceraian.

\section{PENUTUP}

\section{Simpulan}

Berdasarkan keseluruhan paparan dan analisis di atas dikekemukakan kesimpulan sebagai berikut :

a. Hukum yang diterapkan oleh hakim terhadap hak asuh anak akibat perceraian dari beberapa kasus konkrit yakni hukum nasional, meskipun di Bali sangat kental berlaku sistem kekerabatan patrilineal atau sistem purusa.

b. Faktor-faktor yang menjadi dasar pertimbanganhakimdalammenetapkan hak asuh anak akibat perceraian yaitu Undang-Undang Perkawinan dan Undang-Undang Perlindungan Anak, hal-hal yang menjadi menyebabkan terjadinya perceraian, kepentingan dan terjaminnya masa depan depan anak, pengasuhan anak-anak di pihak ibu tidak menggugurnya hak mewaris anak pada ayahnya dan, sistem kekeluargaan patrilineal yang berlaku di Bali tidak mempengaruhi hakim dalam menetapkan hak asuh anak akibat perceraian.

\section{Saran}

Berdasarkan kajian-kajian di atas maka melalui laporan penelitian dapat disarankan kepada para hakim hendaknya terus menjadikan kepentingan dan terjaminnya masa depan anak sebagai dasar dalam menetapkan hak asuh anak dalam perceraian, akan tetapi tetap melestarikan nilai-nilai hukum adat sepanjang tidak bertentangan dengan prinsip-prinsip hukum negara.

\section{DAFTAR PUSTAKA}

Chohen, Moris L. \& Ken C. Olson, 1992, Legal Research, West Publishing Company, St. Paul, Minn.

Friedman, L.M., 1977, Law and Society, anIntruduction, Printice Hall, New Jersey.

Fuady,Munir, 2007, Sosiologi Hukum Kontemporer, Interaksi Hukum, Kekuasaan, dan Masyarakat, PT. Citra Aditya Bakti, Bandung.

Huijbers, Theo, 1982, Filsafat Hukum dalam Lintasan Sejarah, Kanisius, Yogyakarta.

Mertokusumo, Sudikno, 2007, Penemuan Hukum Sebuah Pengantar, Liberty Yogyakarta.

Moore, Sally Falk, 2001, "Hukum dan Perubahan Sosial : Bidang Sosial Semi 
(UDAYANA MASTER LAW JOURNAL)

Otonomi Sebagai Suatu Studi Yang Tepat", dalam Antropologi Hukum Sebuah Bunga Rampai, Penyunting T.O. Ihromi, Yayasan Obor, Jakarta.

Muhamad, Bhusar, 2003, Asas-Asas Hukum Adat Suatu Pengantar, Pradnya Paramita, Jakarta.

Rahardjo, Satjipto, 2009, Penegakan Hukum Suatu Tinjauan Sosiologis, Genta Publishing, Yogyakarta.

Saragih, Djaren, 1980, Pengantar Hukum Adat Indonesia, Tarsito, Bandung.

Soekanto, Soerjono, 1988, Pendekatan Sosiologis Terhadap Hukum, PT Bina Aksara, Jakarta.

Soekanto, Soerjono, 1983, Faktor-Faktor Yang Mempengaruhi Penegakan Hukum, Raja Grafindo Persada, Jakarta.

Soepomo, R., 1986, Bab-Babtentang Hukum Adat, Pradnya Paramita, Jakarta.

Sudantra, I Ketut, I Gusti Ngurah Sudiana, Komang Gede Narendra, 2011, Perkawinan Menurut Hukum Adat Bali, Udayana Universiry Press.

Wiranata, I Gede A.B., 2005, Hukum Adat Indonesia (Perkembangannya dari Masa ke Masa), PT Citra Aditya Bakti, Bandung.

Tahamaha, Brian Z., 2006, Jurisprudence of Law and Society. Oxford University Press, New York. 